\title{
African kimberlites revisited: in situ Sr-isotope analysis of groundmass pervoskite
}

\author{
Jon D. Woodhead, David Phillips, Janet M. Hergt and Chad Paton \\ School of Earth Sciences, The University of Melbourne, 3010 Victoria, Australia \\ (jhergt@unimelb.edu.au / Fax: +6138344 7761)
}

\begin{abstract}
Although isotopic data have been employed for many years in the study of mantle-derived rocks, obtaining reliable primary magmatic signatures for kimberlitic rocks has proved problematic owing to the combined effects of crustal contamination and element mobility during weathering processes. Heaman (1989) first suggested a possible method for circumventing these problems by analysis of groundmass perovskite $\left(\mathrm{CaTiO}_{3}\right)$, a phase that is both robust during weathering and free of entrained materials. This approach has not been widely adopted, however, possibly owing to the difficulty in efficiently separating often very small ( $<50$ micron) perovskite grains for chemical analysis.
\end{abstract}

Recently we have developed methods for in situ Srisotopic analysis of groundmass perovskite using laser ablation multi-collector ICPMS (Woodhead et al., 2005; Paton et al., 2007a; Fig. 1) and showed that this technique greatly improved both the reliability and resolution of Sr-isotope results in a study of Indian kimberlites (Paton et al., 2007b; Fig. 2).

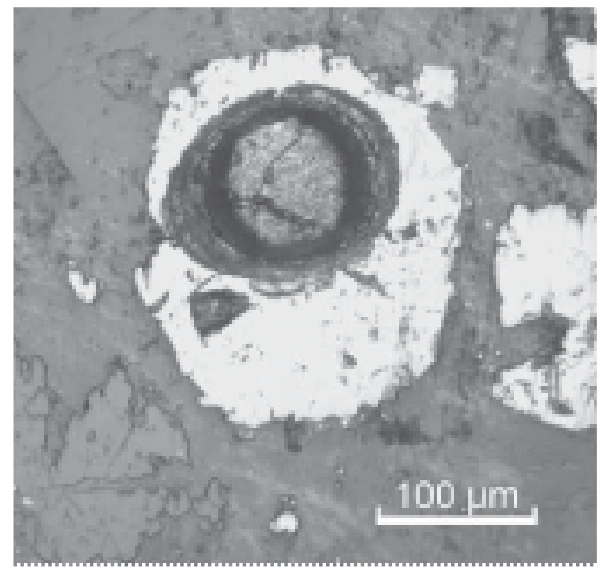

Fig. 1. Groundmass perovskite (pale grey) into which a $93 \mu \mathrm{m}$ diameter laser ablation pit has been drilled during analysis (Polished thick section, reflected light). From Paton et al. (2007b).

Following on from this success we decided to revisit the classic Sr-isotope study of South African kimberlites by Smith (1983). A suite of African kimberlites encompassing over 40 individual intrusions, representing both group I and II types, and covering both on- and off-craton locations has been analysed using these new methodologies.
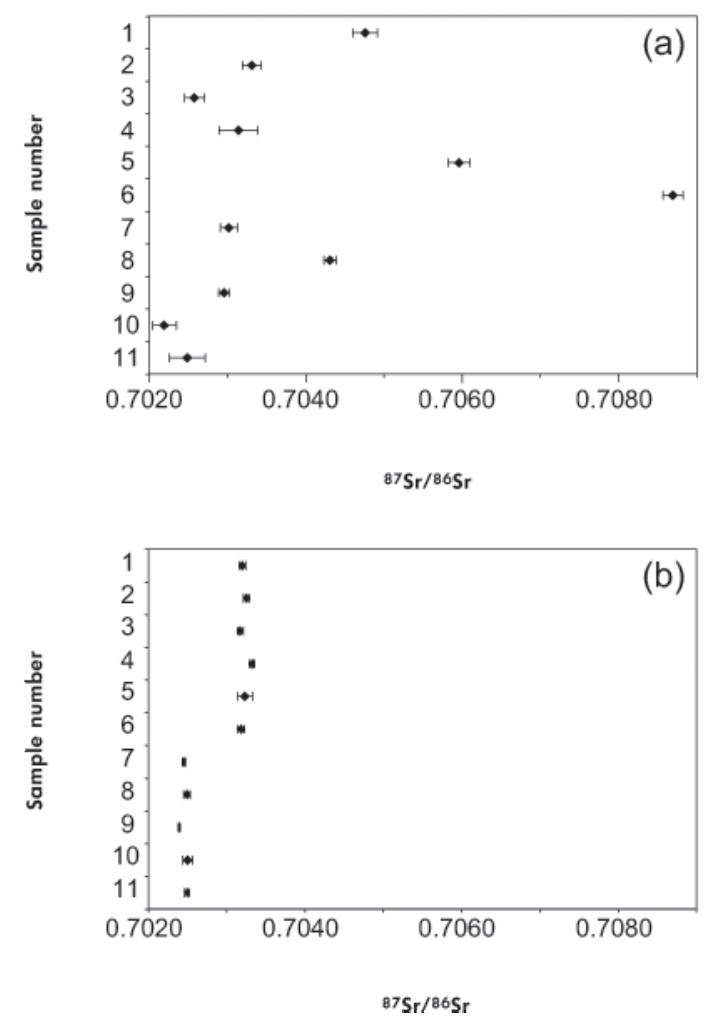

Fig. 2. Comparison between conventional bulk-rock solution $\mathrm{Sr}$ isotope data (a) and in situ perovskite data (b) for 11 Indian kimberlites from two fields. The scatter in initial $\mathrm{Sr}$ isotope values in the bulk-rock data is resolved into two distinct populations using perovskite analyses, revealing homegeneity within, and a subtle difference between, the magmas in each field (see Paton et al., 2007a and 2007b for further details). From Paton et al. (2007b).

We will present our new data, discuss further analytical refinements (especially for the analysis of Group II perovskites which are often $\sim 20$ micron in size), and suggest options for future work. A few initial observations can be made here. First, unlike the data illustrated in Figure 2 above, there is far closer agreement between published bulk-rock $\mathrm{Sr}$ isotope analyses for kimberlites from southern Africa and the 
new perovskite data from our study. Thus, despite rare discrepancies (of up to $\sim 0.003$ in one case), the broad arrays for Group I and Group II kimberlites remain very similar to those already reported in the literature (Fig. 3). Second, we see no evidence for any variations between Group I kimberlites that correlate with their emplacement on- or off-craton. Consequently, the $\mathrm{Sr}$ isotope data do not require (and indeed may not be able to accommodate) the significant involvement of any lithospheric component in these magmas. Finally, at least in the case of Group I samples, there are variations that do not correlate with age and appear to reflect substantial differences in the source regions from which the magmas originated.

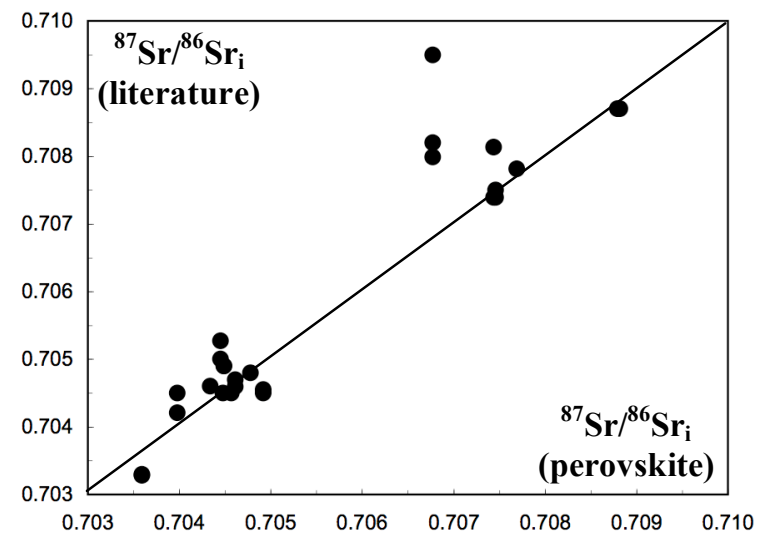

Fig. 3. ${ }^{87} \mathrm{Sr}^{86} \mathrm{Sr}_{\mathrm{i}}$ data for Group I and Group II kimberites from our study, compared with equivalent data reported in the literature (e.g., Smith, 1983; Becker \& le Roex, 2006). The datasets are very similar as indicated by their proximity to a $1: 1$ line. Some samples reported in the literature plot at significantly higher ${ }^{87} \mathrm{Sr} /{ }^{86} \mathrm{Sr}_{\mathrm{i}}$ values, although not to the same extent observed in Figure 2.

\section{Acknowledgements}

The authors would like to thank De Beers for their support in providing samples for this study.

\section{References}

Becker, M., \& le Roex, A.P., 2006. Geochemistry of South African on- and off-craton, Group I and Group II kimberlites: petrogenesis and source region evolution. Journal of Petrology 47, p. 673-703.

Heaman, L.M., 1989. The nature of the subcontinental mantle from $\mathrm{Sr}-\mathrm{Nd}-\mathrm{Pb}$ isotopic studies on kimberlitic perovskite: Earth and Planetary Science Letters 92, p. 323-334.

Paton, C., Woodhead, J.D., Hergt, J.M., Phillips, D., \& Shee, S., 2007a. Strontium Isotope Analysis of Kimberlitic Groundmass Perovskite via LA-MCICP-MS Geostandards and Geoanalytical Research 31, p. 321-330.

Paton, C., Hergt, J.M., Phillips, D., Woodhead, J.D. \& Shee, S.R., 2007b. New insights into the genesis of Indian kimberlites from the Dharwar Craton via in-situ Srisotope analysis of groundmass pervovskite. Geology 35, 1011-1014.

Smith, C.B., 1983. $\mathrm{Pb}, \mathrm{Sr}$, and $\mathrm{Nd}$ isotopic evidence for sources of southern African Cretaceous kimberlites. Nature, Lond., 304, 51-54.

Woodhead, J., Swearer, S., Hergt, J. \& Maas, R., 2005. In situ Sr-isotope analysis of carbonates by LA-MCICP-MS: interference corrections, high spatial resolution and an example from otolith studies: Journal of Analytical and Atomic Spectrometry, 20, $22-27$. 